\title{
BRD4 Gene Mutation
}

National Cancer Institute

\section{Source}

National Cancer Institute. BRD4 Gene Mutation. NCI Thesaurus. Code C150825.

A change in the nucleotide sequence of the BRD4 gene. 